\title{
Sustainable Development of Rural Settlements from the Perspective of World Heritage: A Case Study of Fujian Tulou
}

\author{
Junwen Zhou \\ SCHOOL OF GEOGRAPHICAL SCIENCES, Fujian Normal University, Fuzhou, Fujian, China \\ E-mail: zhoujunwen2000@gmail.com
}

\begin{abstract}
Fujian Tulou has a long history and profound cultural deposits. In 2008, the 32nd Session of the UNESCO World Heritage Assembly included it in the World Heritage List. This paper briefly summarizes the architectural structure and ecological environment of Fujian Tulou, and compares the architectural characteristics and significance of other rural settlements in the world. Finally, the paper analyzes the four aspects of Fujian Tulou, and puts forward relevant suggestions from the direction of sustainable development.
\end{abstract}

Keywords: World cultural heritage, sustainable development, rural settlements, Fujian Tulou

\section{INTRODUCTION}

There are generally three types of world heritage, namely cultural heritage, natural heritage and double heritage. The rural settlements discussed in this paper are the world cultural heritage. Under the action of the current economic mechanism, the central urbanization process is rapid, local governments blindly pursue economic development, but ignore the cultural value of ancient relics, leading to severe damage to many rural settlements. As an important part of the sustainable development of ecological civilization, the exploration, development, research and protection of rural settlements are the problems that need to be solved.

As an important coastal city in south China, Fujian has a kind of architecture that is not only famous locally, but also in the world. Taking Tulou in Fujian province as an example, this paper analyzes the spatial structure of rural settlements and deeply discusses the sustainable development direction of traditional villages in the perspective of world heritage in the new era.

\section{TULOU SETTLEMENT STRUCTURE AND ECOLOGICAL AND ENVIRONMENT IN FUJIAN PORVINCE}

\subsection{SITE SELECTION MODE OF LEANING AGAINST MOUNATINS AND RIVERS}

Fujian is a subtropical Marine monsoon climate, high temperature and rainfall in summer, cold and dry in winter, often accompanied by typhoons in summer.

Fujian Tulou settlements concentration distribution in the mountain valley MinXiNa area, terrain more for low hills and basin, rich in forest resources (figure 1), Tulou settlement as the mountains surround close limit big space, with vertical structure according to the step by step a terrace on the space configuration, back to the forest soil, comply with the stream flow to the extension of the architectural layout forms to ensure good water supply, ventilation and plenty of light, at the same time satisfy the convenience of daily water intake (figure 2) [1]. 


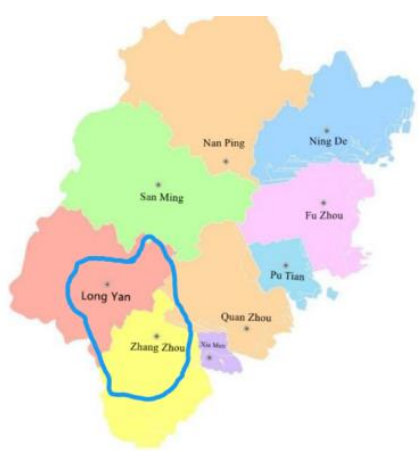

Figure 1 Fujian Tulou main distribution map

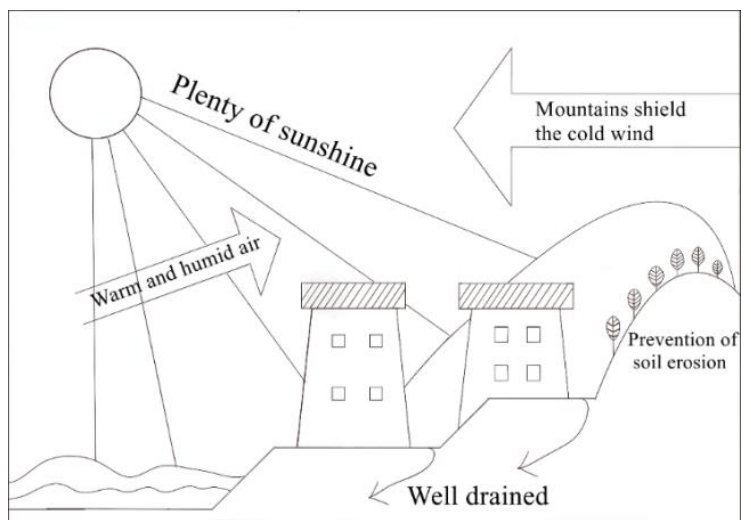

Figure 2 Fujian Tulou ecological diagram

\subsection{ARCHITECTURAL PATTERN}

As a symbolic product of ancient people's wisdom in building, Fujian Tulou has various styles and unique shapes. In terms of plane layout, Fujian Tulou is enclosed by courtyard inside and outside. The distribution of corridors and rooms is spread out with public areas such as halls and doorways as the central axis. The inner circle is generally used as public area to provide some social space, while the outer circle is used as living place to ensure the daily life of residents [2]. In the three-dimensional structure, the first and second floors are used as the infrastructure, and the first floor is usually used as the kitchen. This is because the first floor of the earth building is composed of rocks and rammed earth. The kitchen on the first floor can not only play a certain role in fire prevention, but also reduce the upward transportation of water vapor. Floors above is living place, give priority to with woodiness structure commonly, it is to solve bearing problem on one hand, it is to ensure inhabitant to live on the other hand comfortable, in order to obtain the purpose of winter warm summer cool.

\subsection{THE SETTLEMENT LAYOUT OF HARMONY BETWEEN HEAVEN AND MAN}

At the beginning of construction, any building has the choice of seeking good luck and avoiding evil,it is the embodiment of the idea of harmony between man and nature in architecture. Tulou is generally close to low mountains and hills, facing flat areas with broad vision. The purpose is to defend against Japanese pirates built on terraces, forming a natural terrain surrounded by mountains and rivers, backed by mountains and facing open cliffs. It can not only defend against the enemy's attack from high places, but also facilitate the pumping of water for farmland, which is conducive to agricultural development.

\subsection{BASIC FEATURES OF FUJIAN TULOU}

Tulou are mainly distributed in the south and southwest of Fujian, with the most densely distributed in the northwest of Yong ding County and Nanjing County and the southwest of Longyan City. In addition, they are also sporadically distributed in Zhangpu, Longhai in Chungrian, Anxi, Dehua, Hui 'an, Nan 'an, Tong 'an in Xiamen and other places [3].

Fujian Tulou buildings involves religion and ritual in ancient China, education and science and technology and other fields, it profoundly affected the architectural features of Fujian min nan region, and in some parts of Guangdong province architectural style, and indirectly affect the region's cultural idea and the family tradition, is a shining pearl on the ancient Chinese architectural history, is testament to the existing architecture can reflect the family culture.

\section{COMPARATIVE STUDY OF RURAL SETTLEMENTS}

The 44th World Heritage Conference will be held in Fuzhou on July 16, 2021. Up to now, there are 11 recorded ancient villages, most of which are distributed in Asia and Europe, while others are scattered in Africa and America. In this paper, some of the ancient villages will be compared. Through the comparison between Fujian Tulou and other ancient villages in the World Heritage, it is easy to see that Fujian Tulou has a long construction time, distinctive characteristics and high cultural value.

Table 1. Characteristics and significance comparison of rural settlements on the World Heritage List

\begin{tabular}{ccccc}
\hline $\begin{array}{c}\text { The serial } \\
\text { number }\end{array}$ & The name of the & countries & history & Architectural features and significance \\
\hline 1 & Fujian Tulou & China & $\begin{array}{c}\text { From the 15th century to the } \\
\text { 20th century, it first began } \\
\text { in the Song and Yuan } \\
\text { dynasties }\end{array}$ & $\begin{array}{c}\text { A multi-story, round or square earthen } \\
\text { building designed to unite the family and } \\
\text { defend against foreign enemies }\end{array}$ \\
\hline
\end{tabular}




\begin{tabular}{|c|c|c|c|c|}
\hline 2 & $\begin{array}{c}\text { Kaiping Diaolou and } \\
\text { Villages }\end{array}$ & China & $\begin{array}{c}\text { 19th } \sim 20 \text { th century till now, } \\
\text { the earliest date back to the } \\
\text { late Ming and early Qing } \\
\text { Dynasty }\end{array}$ & $\begin{array}{l}\text { The multi-storey tower-style rural } \\
\text { residence is a fusion of Chinese and } \\
\text { Western architectural styles, with functions } \\
\text { of both defense and residence }\end{array}$ \\
\hline 3 & $\begin{array}{l}\text { Historic Villages of } \\
\text { Shirakawa-go and } \\
\text { Gokayama }\end{array}$ & Japan & 11 th century to present & $\begin{array}{l}\text { A two-story structure with a steep, thatched } \\
\text { roof, slightly larger than the average } \\
\text { farmhouse. }\end{array}$ \\
\hline 4 & $\begin{array}{l}\text { Historic Villages of } \\
\text { Korea: Hahoe and } \\
\text { Yangdong }\end{array}$ & $\begin{array}{l}\text { South } \\
\text { Korea }\end{array}$ & $\begin{array}{c}14 \text { th } \sim 15 \text { th century to } \\
\text { present }\end{array}$ & $\begin{array}{l}\text { Backed by green hills and woods, facing } \\
\text { the river and farmland, beautiful scenery, } \\
\text { picturesque }\end{array}$ \\
\hline 5 & $\begin{array}{l}\text { Old Village of Holloko } \\
\text { and its Surroundings }\end{array}$ & $\begin{array}{c}\text { In } \\
\text { Hungary, }\end{array}$ & $\begin{array}{c}17 \text { th } \sim 18 \text { th century to } \\
\text { present }\end{array}$ & $\begin{array}{l}\text { Set at the foot of the Matka Mountains, the } \\
\text { thatched roof shows rural life before the } \\
\text { agricultural revolution of the 20th century }\end{array}$ \\
\hline 6 & $\begin{array}{l}\text { Hola š ovice Historical } \\
\text { Village Reservation }\end{array}$ & $\begin{array}{l}\text { The Czech } \\
\text { republic }\end{array}$ & $\begin{array}{c}18 \text { th } \sim 19 \text { th century to } \\
\text { present }\end{array}$ & $\begin{array}{l}\text { A well-preserved specimen of a traditional } \\
\text { village in Central Europe, in the famous } \\
\text { "Southern Bohemian Folk Baroque style" }\end{array}$ \\
\hline 7 & $\begin{array}{l}\text { Villages with Fortified } \\
\text { Churches in } \\
\text { Transylvania }\end{array}$ & Romania & 13 th-16th century to present & $\begin{array}{c}\text { The village was accompanied by a fortified } \\
\text { church, an important episode in the history } \\
\text { of architecture between the 13th and 16th } \\
\text { centuries }\end{array}$ \\
\hline 8 & $\begin{array}{c}\text { Ksar of } \\
\text { Ait-Ben-Haddou }\end{array}$ & Morocco & 17 th century to present & $\begin{array}{l}\text { The village is a group of earthen buildings } \\
\text { enclosed by high walls, with many houses } \\
\text { built within the defensive walls, } \\
\text { supplemented by towers of arrows }\end{array}$ \\
\hline 9 & Pueblo de Taos & $\begin{array}{l}\text { The } \\
\text { United } \\
\text { States }\end{array}$ & 13th-14th century to present & $\begin{array}{l}\text { Mainly made of mud bricks and stone } \\
\text { bricks, the village is composed of } \\
\text { dwellings and religious ceremony } \\
\text { buildings, displaying the culture of the } \\
\text { Indians }\end{array}$ \\
\hline
\end{tabular}

\section{PRESENT SITUATION AND PROBLEMS OF FUJIAN TULOU}

The problems of Fujian Tulou are as follows: (1) local tourism and residents benefit. Tourism has become an important economic source of Fujian Tulou attractions. However, the tourism development cost of Fujian Tulou is usually borne by the whole residents, and the beneficiaries are mostly from tourism companies and enterprises, while the interests of local residents are ignored. (2) Health problems. In the Tulou dwellings, a well is the water source for people to live on [4]. The groundwater used for human and animal life is all public groundwater, which leads to the poor sanitation conditions and insufficient disinfection conditions, which may lead to the spread of viruses through water. (3) Structural safety of aging buildings. Fujian Tulou is an architectural structure system of civil cooperation based on wood structure and is based on rock and soil foundation. Located along the Pacific Seismic belt, Fujian province has a subtropical monsoon climate and is hot and dry in summer. Once natural disasters occur, it is extremely difficult for residents in the Tulou to escape and rescue. (4) The preservation strategy is backward, and the traditional buildings die out. First, The ancient villages protection strategy is relatively backward, and the protection work is also lagging behind [5]. The monitoring system of Fujian Tulou daily repair is not scientific and systematic enough, and it is not helpful to the overall building disaster prevention. Second, modern life people emphasize privacy, private life, some residents from Tulou, near the Tulou building opposite or self-built. Third, in order to pursue better living conditions, young people yearn for city life, which only leads to the gradual abandonment of the Tulou.

\section{RESEARCH ON SUSTAINABLE DEVELOPMENT OF FUJIAN TULOU}

\subsection{RESIDENTS SHARE DIVIDENDS, CULTURAL AND CREATIVE INDUSTRY DEVELOPMENT}

Separate development of the tourism industry, ignore the benefit of the community, will be harmful to the Tulou tourism development. Improve Tulou in the proportion of residents within the travel company shareholders, the interests of residents and enterprises. To develop special tourism and industry, using the advantage of location factors, Tulou rooms available for development, integrated into the commercial and artistic elements, make full use of the Tulou culture, selling special product, such as Tulou style mug, refrigerator, etc., to create unique Tulou local cultural brand, rich community residents income, improve the economic structure, is advantageous to the Tulou additional value to the development of tourism culture, will greatly boost the enthusiasm of the residents for the Tulou tourism development, automatic development work independently. 


\subsection{IMPROVE THE HEALTH AWARENESS OF THE RESIDENTS AND MAKE FULL USE OF MODERN TECHNOLOGY}

Increase health security awareness, training of community residents, community residents' health and safety of the whole awareness, change traditional residents water hygiene, use tap water instead of underground Wells, the separation of human and animal living area and living water, sewage, scientific processing waste, ensure the neatness of the Tulou internal clean; Residents of household water purification processing system installation, to control the extraction of groundwater, e. coli in Wells installed detector and antivirus treatment, the greatest degree protection Tulou near water security.

\subsection{REPAIR OLD BUILDING STRUCTURES AND CHANGE RESIDENTS' LIVING HABITS}

The first is to improve the awareness of daily life of Tulou residents, give up traditional firewood fires and use safer energy sources such as natural gas to reduce the possibility of fire. Second, in the largest reduction under the condition of architectural history style and features, to renovation of building materials, emerging light building materials to replace the old wooden materials, and fire retardant paint brush on the shell from the hardware protection Tulou, at the same time of fire prevention, reduce weight in order to prevent the largest earthquake bring more severe damage.

\subsection{MAKE UNIQUE POLICIES FOR FUJIAN TULOU ACCORDING TO LOCAL CONDITIONS}

In view of the special historical environment and building structure of the Tulou, the relevant departments need to make special policies and guidelines for the Tulou based on the local natural and cultural background. (1) For the mountainous environment where the earth buildings are located, the surrounding construction should be improved, water conservancy tools should be established, agricultural modernization and automation should be realized, and high voltage power lines should be built to improve the living convenience of community residents.(2) Attract investment, provide more preferential tax policies and economic subsidies for the enterprises that invest, reasonable economic investment can promote the local economic development, attract young people to stay in their hometown, return to their hometown to start their own business and construction.(3) To improve the internal structure of Tulou, in view of the phenomenon of multiple generations living under the same roof, the housing structure should be reconstructed, the adjacent units should be merged, and the per capita living area should be increased. Recreational facilities should be built to promote mutual communication among residents in the building and enhance their happiness in life.

\section{CONCLUTION}

China's rural areas are vast and populous. In the process of accelerating urbanization, unreasonable land use and spatial structure differentiation in rural areas are inevitable. The Fujian Tulou as a unique building in the world, declared world heritage in after the success, also want to pay attention to protect further, from the perspective of historical and cultural heritage, the Fujian Tulou reflects the culture of family ties and the volunteer spirit of solidarity. From the perspective of natural ecological environment, the protection of Fujian Tulou can reflect the sustainable development direction of rural settlements in the new era.

\section{REFERENCES}

[1] Mengyao Zhao, Yuhua Zhang. Research on architectural Characteristics and protection of Fujian Tulou [J]. Modern Property (mid-day),2020(04):44-45.

[2] Yaling Gao, Minghuan Zhang, Xianshu Xu. Research on spatial morphology characteristics of Tulou settlements in Fujian province [J]. Fujian Architecture,2020(02):16-20.

[3] Yaling GAO. Study on Landscape Protection of Ancient Tulou Villages in Fujian province [D]. Fujian Agriculture and Forestry University, 2012.

[4] Jun Ma. Sustainable development of Hakka earth buildings in Yongding from ecological adaptability [J].Art Exploration,2008(05):28-29.

[5] Yangxing Liu. Research on conservation strategies of ancient villages from the perspective of cultural Heritage protection $[\mathrm{J}]$. China National Expo, 2019(8):55-56. 